\title{
ROLE OF AGRICULTURAL EDUCATION FARM WORKSHOP IN DEVELOPMENT OF STUDENTS' SKILLS IN INDIGENOUS MECHANIZED TECHNOLOGY FOR SELF-RELIANCE IN RIVERS STATE
}

\author{
Aleru P.D. and Lazarus S.T. \\ Department of Vocational and Technology Education, Rivers State University, Port Harcourt \\ Email: aleruprince5893@gmail.com
}

Cite this article:

Aleru P.D., Lazarus S.T.

(2021), Role of Agricultural

Education Farm Workshop in

Development of Students'

Skills in Indigenous

Mechanized Technology for

Self-Reliance in Rivers State.

British Journal of

Contemporary Education 1(1), 64-74. DOI: 10.52589/BJCEPDJKIJBC.

\section{Manuscript History \\ Received: 18 Aug 2021 \\ Accepted: 13 Sept 2021 \\ Published: 27 Sept 2021}

Copyright $\odot 2020$ The Author(s). This is an Open Access article distributed under the terms of Creative Commons AttributionNonCommercial-NoDerivatives 4.0 International (CC BY-NC-ND

4.0 ), which permits anyone to share, use, reproduce and redistribute in any medium, provided the original author and source are credited.
ABSTRACT: The study examined the role of agricultural education farm workshops in development of students' skills in indigenous mechanized technology for self-reliance in Rivers State. Two research questions and two hypotheses were formulated for the study. The study adopted a descriptive research design. The sample size for the study was 293 respondents $(278$ students and 15 agricultural education lecturers) in the study area. The instrument for data collection was a self-structured questionnaire designed in a 4-point rating scale of agreement. The reliability of the instrument was established using the test-retest method which yielded 0.82. Data was analyzed using mean and standard deviation with a criterion mean value of 2.50 and above while a z-test statistical tool was used to test the null hypotheses at a significance level of 0.05 . Findings from the study revealed that agricultural education workshop gives students access to hands-on-experience on the production of indigenous mechanized technologies for farming activities, improves students' skills in construction and installation of agricultural indigenous mechanized tools. The study also revealed that agricultural education farm workshops inculcate students with the required skills in maintenance of indigenous mechanized farm equipment and aid students access to industrial workshop activities. Based on the findings, the study recommends that government at all levels should provide wellequipped farm workshops for agricultural education programmes to train and inculcate students with the necessary skills that will enhance the fabrication of agricultural indigenous mechanized technology.

KEYWORDS: Role, Farm, Workshop, Skills, Indigenous, Mechanized, Technology 


\section{INTRODUCTION}

Production of agricultural inputs such as indigenous technologies for farming activities plays a unique role in poverty reduction among youths in developing countries. Lipton (2001) asserts that no other sector than agricultural enterprise has the possibility to create employment and lift the youths out of poverty. In this regard, Amadi, Agumagu and Edna (2007) asserted that problems of mechanized technology usage and subsistence farming can only be solved with the aid of vocational agricultural education. In recognition of this fact, agricultural education farm workshops are presently being utilized as one means of providing the practical experiences needed for students to fabricate/manufacture indigenous mechanized technology for agricultural production.

Agricultural productivity will not be fully enhanced in Nigeria until there is good utilization of mechanized technology and the willingness of youth to be in the fabrication sector. Students are admitted into vocational agricultural education programmes each year with a diversity of abilities, ambitions, training and expectations. According to Ibrahim, Olayinka, and Ololade (2013), if agricultural production is to be sustainable, students must be empowered with appropriate skills, knowledge and attitude towards farming and the manufacturing of indigenous technologies for agricultural production. This will enhance agricultural productivity and food security for all in the immediate, medium and long terms on a sustainable basis. Hence, focusing on the development of indigenous mechanized agricultural technology will at its fundamental level improve youths' production skills in agriculture.

Agricultural indigenous mechanized technology is a key input in the farming system. It aims to achieve the following:

- Easy access to improved farm technology at low cost.

- Improved productivity of labour.

- Reduction of drudgery in farming activities, thereby making farm work more attractive for farmers.

- An expansion of the area under cultivation where land is available.

- Increased productivity per unit area as a result of improved timeliness of farm operations;

- Improvements in the quality of work and products.

Farm workshops are needed to fabricate, maintain, repair and install equipment and keep tools in one location for all kinds of agricultural production activities. Agricultural education farm workshop plays a key role as a resource for students' participation in the production of agricultural inputs such as technologies, improved seedling, etc required for agricultural development. The activities carried out in agricultural education farm workshops gives students insight into areas of production to support the local farming sector and revitalize the local manufacturing movement. Students' fabrication of indigenous mechanized agricultural technologies enables farmers to get the right tools at hand and the subsidized price. 
The development of agricultural indigenous mechanized technology contributes to the reduction of poverty and unemployment globally. According to Stephen (2011), technology is the combination of resources to produce desired products to solve problems, fulfil needs or satisfy wants. It includes technical methods, skills, processes, techniques, tools and raw materials. Ngoka (1992) regard indigenous technology as technologies employed by the native inhabitants of a country and which constitute an important part of its cultural heritage and should therefore be protected against exploitation by industrialized countries. Agricultural indigenous mechanized technologies are tools and pieces of equipment that are developed through the initiative of the dwellers using local contents to reduce the drudgery and enhance food production. Dayanatha (2006) asserts that indigenous technology is generally low capital intensive and since they are usually environment and ecology friendly, they are also sustainable, accessible and diffuse over small homogenous zones mainly by farmers to farmers interaction. Indigenous technologies have historically made valuable contributions to agricultural production and cultural heritage.

Indigenous technologies are products of creativity and innovations developed through gradual learning processes and hands-on experience in the workshop. Thus, vocational agricultural farm workshop serves as an avenue for students to learn valuable skills in indigenous mechanization and other aspects of farm management. According to Zinner (2009), it is the responsibility of agricultural education to develop in each student, the skills, attitudes and knowledge required to be responsible and productive individuals. Students could venture into fabrication, installation and maintenance of indigenous mechanized agricultural technologies as an enterprise to promote farming activities, thus becoming self-reliant in the society. Correspondingly, Azogu (2009) asserts that many functional agricultural centres have developed technologies that encouraged the use of mechanized technology through the fabrication of several indigenous machines like manual seed planter, manual seed and fertilizer broadcaster and groundnut digger among others with the training of youths on how to locally fabricate these machines for employment generation. Students could also develop skills for the fabrication of indigenous technologies like cassava lifter, peeler, grater and hand mill through participatory activities in the workshop for self-empowerment.

Okorafor (2014) stated that the skills required for the production of indigenous technology are enhanced through adequate utilization of well-equipped farm workshops. Onwualu (2008) observing the role of farm workshop stated that it gives students the ability to operate and maintain a new production based on the need of farmers to maximize production thus becoming self-employed. He further explained that farm workshop develops students' capacity to design and duplicate imported mechanized tools that fit the environment of the users. Similarly, students develop skills to undertake new designs and fabrication of components/spare parts needed for replacement and repair in indigenous technology. According to Masayuki (2004), well-equipped farm workshops boost students' skills in the fabrication of mechanized tools with local content resources for agricultural production. With these skills, students could own enterprises for the fabrication and marketing of mechanized equipment after graduation hence, reducing the high rate of importation of agricultural machines. Larry (2010) asserts that agricultural education farm workshop provides students with an easy-to-understand, safetyconscious introduction to the processes of welding mechanized agricultural technologies and techniques. Farm workshop improves students' experience in metal fabrication technology in agricultural production. 
Agricultural education farm workshop enables students to meet the demand from small organic farms for affordable, precise, and reliable farm equipment. Kris (2015) posits that farm workshop gives agricultural education students room to develop skills required to build and test prototypes for farming activities. Similarly, According to Larry (2010), farm workshop provides skills for brazing and production of specialized metallic fabricated technologies to students who are users of the facility. Activities in farm workshops enhance students' skills in welding all types of agricultural machinery needed in agriculture. Similarly, Monica, Kirsty, Mark, Gediminas and Ellen (2011) asserted that farm workshops play a role in developing students' skills in light metal welding and other production of locally made farm machines to maximize production for rural farmers.

One objective of the agricultural education programme is the provision of efficient agricultural workshops for mechanization purposes. This was made clear in the first legislative commitment for vocational education in agriculture held in 1917 (Smith-Hughes Act). As indicated in the act, the agricultural education programme must provide supervised experience to students in farm workshops for at least six months per year. The activities in the workshop instil valuable skills on students for the installation of indigenous fabricated mechanized technologies on high motors for agricultural production for self-reliance. Farm workshops improve students' skills and efficiency in the mounting of fabricated machine parts to the appropriate linkage system for work. It plays a role in developing students' skills in the installation of fabricated cutting plate and blade on equipment handles before use for farming activities. Amadi and Aleru (2016) posited that students could be assigned development tasks in agricultural farm workshop. Such task could be to develop indigenous mechanized rotary beater bars for quality oil palm production. Hence, adequate utilization of farm workshops inculcate students with skills needed for proper fabrication, installation and coupling of various parts of indegenous mechanized technology.

Farm workshop serves as a facility that provides an avenue for students' training on appropriate maintenance of fabricated mechanized agricultural equipment for easy farming. According to Monica, et al (2011), various activities of farm workshops inculcate participants with capacities in replacing/repairing safety faulty machines, sharpening or replacing machines' cutting blades and lubrication. The day-to-day utilization of farm workshops has extensively improved students' ability in the maintenance and repair of the hydraulic motor systems for farmers and other agricultural industries. Maintenance of portable tools such as saws, hammers, screwdrivers, axes and wrenches as well as electrical portable tools like circular saws, drills, motor winch or high-pressure cleaners are part of skills developed from the utilization of farm workshops.

Many researchers have made contributions on ways to develop agriculture in Nigeria, ranging from funding to infrastructural availability. Characteristically, Nigeria has been heavily dependent on foreign technologies as a means to develop agricultural production forgetting the immense contribution of indigenous mechanized fabricated farm equipment. These, however, have not made any relevant improvement in food production. Could this be based on the expensive nature of the imported machines for farming or are the equipment not aligned to the farming system in Nigeria? Could it be the lack of manpower for the production of indigenous mechanized agricultural technologies? Thus, the study examined the role of agricultural education farm workshops in the development of students' skills in indigenous mechanized technology for self-reliance in Rivers State. 


\section{Purpose of the study}

The main purpose of the study was to examine the role of agricultural education farm workshops in the development of students' skills in indigenous mechanized technology for self-reliance in Rivers State. Specifically, the study sought to:

1. Assess the role of agricultural education farm workshop in the development of students' skills in the fabrication of indigenous mechanized technology for self-reliance in Rivers State.

2. Examine the role of agricultural education farm workshop in the development of students' skills in maintenance of indigenous mechanized technology for self-reliance in Rivers State.

\section{Research Questions}

For the purpose of the study, the following research questions were considered to aid the study:

1. What are the roles of agricultural education farm workshops in the development of students' skills in the fabrication of indigenous mechanized technology for self-reliance in Rivers State?

2. What are the roles of agricultural education farm workshops in the development of students' skills in the maintenance of indigenous mechanized technology for selfreliance in Rivers State?

\section{Research Hypotheses}

The following null hypothesis was postulated to guide the study:

1. There is no significant difference in the mean score of students and lecturers on roles of agricultural education farm workshop in the development of students' skills in the fabrication of indigenous mechanized technology for self-reliance in Rivers State.

2. There is no significant difference in the mean score of students and lecturers on roles of agricultural education farm workshop in the development of students' skills in the maintenance of indigenous mechanized technology for self-reliance in Rivers State.

\section{METHODOLOGY}

The study was carried out in Rivers State. Rivers State is a state in the southern part of Nigeria with a total of 23 Local Government Areas. The dominant ethnic groups are Ikwerre, Etche, Ogoni, Ogba, Egbema, Ndoni, Andoni, Opobo and Ekpeye where a majority of the population are rural dwellers who mainly depend on subsistence farming activities for livelihood. The state also has three (3) tertiary institutions (Rivers State University, Ignatius Ajuru University of Education and Federal College of Education Technical) that offer agricultural education programmes. Thus, the researcher was certain that an adequate representative of the population of students and lecturers in this field would be obtained. The study was a descriptive survey research design. The target population was agricultural education students and lecturers in Rivers State tertiary institutions. Hence, the study population consists of 293 which comprises 
54 students and 5 lecturers in RSU, 125 students and 4 lecturers in IAUE and 99 students and 6 lecturers in FCET respectively. No sample was made due to the small size of the population. The instrument used to gather data was a self-constructed questionnaire designed in a 4-point rating scale of agreement which elicited information on each research question. The reliability of the instrument was tested using the test-retest method and a reliability coefficient ( $\mathrm{r}$ ) achieved was 0.84 . Data was analyzed using mean and standard deviation with a criterion mean value of 2.50 and above while a Z-test was used to test the null hypotheses at a significance level of 0.05 .

\section{RESULTS}

Research Question 1: What are the roles of agricultural education farm workshops in the development of students' skills in the fabrication of indigenous mechanized technology in Rivers State?

Table 1: Mean score of respondents on roles of agricultural education farm workshop in development of students' skills in the fabrication of indigenous mechanized technology

\begin{tabular}{|c|c|c|c|c|c|c|c|}
\hline \multirow[t]{2}{*}{$\mathbf{S} / \mathbf{N}$} & \multirow[t]{2}{*}{ Statements } & \multicolumn{3}{|c|}{ Students $(\mathrm{N}=278)$} & \multicolumn{3}{|c|}{ Lecturers $(\mathrm{N}=15)$} \\
\hline & & $\bar{X}$ & SD & Decision & $\bar{X}$ & SD & Decision \\
\hline 1. & $\begin{array}{l}\text { Farm workshops develop students' skills to } \\
\text { undertake new designs of indigenous } \\
\text { equipment }\end{array}$ & 3.34 & 0.76 & Agreed & 3.21 & 0.89 & Agreed \\
\hline 2. & $\begin{array}{l}\text { Workshop activities enhance students' ability } \\
\text { to fabricate indigenous technology components }\end{array}$ & 3.11 & 0.68 & Agreed & 2.87 & 0.97 & Agreed \\
\hline 3. & $\begin{array}{l}\text { Farm workshop develop skills required to build } \\
\text { and test mechanical prototypes }\end{array}$ & 2.98 & 1.04 & Agreed & 3.05 & 0.85 & Agreed \\
\hline 4. & $\begin{array}{l}\text { Improves students' knowledge to braze and } \\
\text { produce specialized equipment for farming } \\
\text { activities }\end{array}$ & 3.01 & 0.59 & Agreed & 3.32 & 0.65 & Agreed \\
\hline 5 . & $\begin{array}{l}\text { Farm workshops enhance students' skills in } \\
\text { welding all types of agricultural machines } \\
\text { needed in agriculture }\end{array}$ & 3.40 & 0.76 & Agreed & 3.12 & 1.12 & Agreed \\
\hline & Grand Mean & 3.17 & 0.77 & Agreed & 3.11 & 0.90 & Agreed \\
\hline
\end{tabular}

Source: Fieldwork 2020

Results from Table 1 shows the mean and standard deviation score of respondents on roles of agricultural education farm workshop in the development of students' skills in the fabrication of indigenous mechanized technology in Rivers State. The study revealed that the respondents agreed that agricultural education farm workshops develop students' skills to design new indigenous equipment ( $3.34 \& 3.21$ ), workshop activities enhance students' ability to fabricate indigenous technology components $(3.11 \& 2.87)$, farm workshop develops skills required to build and test mechanical prototypes (2.98 \& 3.05), improves students' knowledge to braze and produce specialized equipment for farming activities (3.01 \& 3.32) and farm workshop enhance students' skills in welding all types of agricultural machines needed in agriculture 
( $3.40 \& 3.12)$. Table 1 shows that the standard deviation scores are low. This implies that the datasets are not widely spread out.

Research Question 2: What are the roles of agricultural education farm workshops in the development of students' skills in the maintenance of indigenous mechanized technology in Rivers State?

Table 2: Mean score of respondents on roles of agricultural education farm workshop in development of students' skills in maintenance of indigenous mechanized technology

\begin{tabular}{|c|c|c|c|c|c|c|c|}
\hline \multirow[t]{2}{*}{$\overline{\mathbf{S} / \mathbf{N}}$} & \multirow[t]{2}{*}{ Statements } & \multicolumn{3}{|c|}{ Students $(\mathrm{N}=278)$} & \multicolumn{3}{|c|}{ Lecturers $(\mathrm{N}=15)$} \\
\hline & & $\bar{X}$ & SD & Decision & $\bar{X}$ & SD & Decision \\
\hline 1. & $\begin{array}{l}\text { Gives opportunities for students' training on } \\
\text { appropriate maintenance of fabricated } \\
\text { indigenous mechanized equipment }\end{array}$ & 3.07 & 0.67 & Agreed & 3.11 & 0.77 & Agreed \\
\hline 2. & $\begin{array}{l}\text { Inculcate students with skills in the repair of } \\
\text { indigenous hydraulic press }\end{array}$ & 3.01 & 0.73 & Agreed & 3.23 & 0.95 & Agreed \\
\hline 3. & $\begin{array}{l}\text { Enhance students skills for replacing of } \\
\text { cutting blade from cassava peeler }\end{array}$ & 3.10 & 0.86 & Agreed & 3.58 & 0.83 & Agreed \\
\hline 4. & $\begin{array}{l}\text { Farm workshop boost students' skills in } \\
\text { maintenance and replacement of fabricated } \\
\text { mechanized grater frame }\end{array}$ & 3.11 & 0.91 & Agreed & 3.31 & 0.76 & Agreed \\
\hline 2. & $\begin{array}{l}\text { Activities in the workshop enhance students' } \\
\text { skills in the coupling of parts }\end{array}$ & 3.15 & 0.68 & Agreed & 3.54 & 3.17 & Agreed \\
\hline 5. & $\begin{array}{l}\text { Agricultural workshop augment participant } \\
\text { skills in daily preventive maintenance of } \\
\text { electrical equipment such as circular saw }\end{array}$ & 2.88 & 0.81 & Agreed & 3.01 & 0.89 & Agreed \\
\hline & Grand Mean & 3.03 & 0.80 & Agreed & 3.25 & 0.84 & Agreed \\
\hline
\end{tabular}

Source: Fieldwork 2020

Results from Table 2 shows the mean and standard deviation score of respondents on roles of agricultural education farm workshop in development of students' skills in maintenance of indigenous mechanized technology in Rivers State. The study revealed that the respondents agreed that agricultural education farm workshop gives opportunities for students' training on appropriate maintenance of fabricated indigenous mechanized equipment (3.07 \& 3.11), inculcate students with skills in the repair of an indigenous hydraulic press (3.01 \& 3.23), enhance students skills for replacing of cutting blade from cassava peeler ( $3.10 \& 3.58$ ), Farm workshop boost students' skills in maintenance and replacement of fabricated mechanized grater frame (3.11 \& 3.31) and augment participant skills in daily preventive maintenance of electrical equipment such as circular saw $(2.88 \& 3.91)$. The items in Table 2 revealed low standard deviation scores. This indicates that the data points are not widely dispersed from the average mean. 


\section{Hypotheses Testing}

Hypothesis 1: There is no significant difference in the mean score of students and lecturers on roles of agricultural education farm workshop in the development of students' skills in the fabrication of indigenous mechanized technology in Rivers State.

Table 4: Z-test Analysis on mean response of students and lecturers on roles of agricultural education farm workshop in development of students' skills in the fabrication of indigenous mechanized technology

\begin{tabular}{lllllllll}
\hline Categories & $\mathbf{N}$ & $\bar{X}$ & SD & Df & Z-cal & Z-crit & $\boldsymbol{\alpha}$ & Decision \\
\hline Students & 278 & 3.17 & 0.77 & \multirow{2}{*}{291} & 1.65 & 1.96 & 0.05 & Fail to reject \\
& & & & & & & & \\
Lecturers & 15 & 3.11 & 0.90 & & & & & \\
\hline
\end{tabular}

Finding from Table 4 revealed that the $\mathrm{z}$-calculated value obtained was 1.65 while the $\mathrm{z}$ critical stood on a value of 1.96 at a 0.05 degree of freedom. The statistics revealed that the $\mathrm{z}$-cal value was less than the z-crit, thus making the null hypothesis which stated no significant difference in the mean response of students and lecturers on roles of agricultural education farm workshop in the development of students' skills in the fabrication of indigenous mechanized technology in Rivers State to be accepted.

Hypothesis 2: There is no significant difference in the mean response of students and lecturers on roles of agricultural education farm workshop in the development of students' skills in maintenance of indigenous mechanized technology in Rivers State.

Table 4: Z-test Analysis on mean response of students and lecturers on roles of agricultural education farm workshop in development of students' skills in maintenance of indigenous mechanized technology

\begin{tabular}{lllllllll}
\hline Categories & $\mathbf{N}$ & $\bar{X}$ & SD & Df & Z-cal & Z-crit & $\boldsymbol{\alpha}$ & Decision \\
\hline Students & 278 & 3.03 & 0.80 & 291 & 0.88 & 1.96 & 0.05 & Fail to reject \\
Lecturers & 15 & 3.25 & 0.84 & & & & & \\
\hline
\end{tabular}

Findings from Table 5 revealed that the $\mathrm{z}$-calculated value obtained was 0.88 while the $\mathrm{z}$ critical stood on a value of 1.96 at a 0.05 degree of freedom. The statistics revealed that the $\mathrm{z}$-cal value was less than the z-crit. Therefore, the null hypothesis which stated no significant difference in the mean response of students and lecturers on roles of agricultural education farm workshop in development of students' skills in maintenance of indigenous mechanized technology in Rivers State failed to reject (upheld). 


\section{DISCUSSION OF FINDINGS}

Research question 1 indicated that agricultural education farm workshops develop students' skills to design new indigenous equipment, enhance students' ability to fabricate indigenous technology components through their participation in farm workshop activities and develop students skills required to build and test mechanical prototypes with the utilization of local resources available. The finding is in alliance with Onwualu (2008) who explained that farm workshop develops students' capacity to design and duplicate imported mechanized tools that fit the environment of the users. The finding also corroborates with Masayuki (2004) and Kris (2015) who posited that well-equipped farm workshops boost students' skills in the fabrication of mechanized tools with local content materials for agricultural production. The finding also revealed that agricultural education farm workshop improves students' knowledge on brazing and producing specialized equipment for farming activities and enhance students' skills in welding all types of agricultural machines needed for production agriculture. The findings are in agreement with Monica, et al (2011) who opined that farm workshops play a role in developing students' skills in light metal welding and other production of locally made farm machines to maximize production for rural farmers.

Research question 3 indicated that agricultural education farm workshop plays major roles in giving students opportunities for skill training on appropriate maintenance of fabricated indigenous mechanized equipment, inculcating students with skills in the repair of indigenous hydraulic press and other indigenous mechanized technologies. The finding is in line with Onwualu (2008) who observed the role of farm workshop stated that it gives students the ability to fabricate, operate and maintain a new production based on the need of farmers to maximize production thus becoming self-employed. The study also revealed that agricultural education farm workshops enhance students skills in replacing cutting blades from indigenous mechanized technology like cassava peelers, boost students' skills in maintenance and replacement of fabricated mechanized grater frame and augment participant skills in daily preventive maintenance of electrical equipment such as circular saw. The findings aligned with Monica, et al (2011) who stated that agricultural education farm workshops play a role in inculcating participants (students) with capacities in replacing and repairing faulty machines, sharpening of machine cutting blades and lubrication of parts.

\section{CONCLUSION}

From the results of the research, the study, therefore, deduced that agricultural education farm workshops play a major role in developing students' technical know-how on venturing into enterprise for the fabrication, installation and maintenance of indigenous mechanized equipment and other hand tools to eliminate drudgery and improve food production. 


\section{RECOMMENDATIONS}

From the conclusion, the study recommends that:

1. The government of Rivers State should make provision for agricultural farm workshops in schools from the secondary level. This will inculcate students with the required skills to own an enterprise in the production of various indigenous technologies for farming, thus making them self reliant at an early stage.

2. Schools offering agricultural education should ensure farm workshops are adequately equipped and utilized to develop students' skills in the installation and coupling of parts.

3. Regular maintenance activities should be carried out on indigenous mechanized technologies available in the farm workshop. This will enhance students' skills in proper maintenance on farmers' machinery equipment after graduation, therefore, increasing their self-dependency and making them useful in society.

\section{REFERENCES}

Amadi, N.S \& Aleru, P.D (2016). Impact of practical agriculture in development of agricultural skills in senior secondary school students in Ikwerre Local Government Area of Rivers State. Journal of Technical and Science Education (JOTASE) 19, (2) 140-148

Amadi, N.S, Agumagu, A.C \& Edna, C.M (2007). Perceived Difficulties Associated with Utilization of Farm Machines among Farm Workers in Rivers State, Nigeria. Journal of Agriculture and Social Research (JASR) 7, (2) 66-71

Azogu, I. I. (2009). Promoting appropriate mechanization technologies for improved agricultural productivity in Nigeria: the role of the National Centre for Agricultural Mechanization. Journal of Agricultural Engineering and Technology (JAET) 17 (2) 43 58.

Ibrahim, F.A, Olayinka, J.Y \& Ololade L.S (2013). Farm Practical Training Programme for Agricultural Students: Case Study of Pioneer Students, Kwara State University, Nigeria. Journal of Sustainable Development in Africa 15, (8) 25-41

Kris, D (2015). Fabricating indigenous equipment: the slow tool project. No Tech Magazine, 2015

Larry, J (2010). Metal Fabrication Technology for Agriculture Hardcover - Illustrated, 19 Jan. 2010s

Lipton, M (2001). Reviving global poverty reduction: What role for genetically modified plants. Journal of International Development, 13 (7) 823-846

Masayuki, T (2004). The role of traditional Japan's industrialization: A perspective of indigenous development. http:econpapers.repec.org/paper/tkyfseres/2004cf275.htm. [Accessed Friday, October 16, 2020] 
Monica A.M, Kirsty O, Mark L, Gediminas V, \& Ellen S (2011). Maintenance in Agriculture: A Safety and Health Guide. European Agency for Safety and Health at Work (EUOSHA).

Okorafor, A.O (2014). Developing indigenous technology for harnessing local natural resources in Nigeria: The place of Technical Vocational Education and Training. International Journal of Science and Technology 3 (8) 461-466

Stephen J.I (2011). Indigenous Technology and Agricultural Production: The Case of Poultry Incubator. International Journal of Poultry Science 10 (6): 493-495 